\title{
The Impact of the Economic Freedom on Foreign Direct Investment in the Arab Countries
}

\author{
[Rasha Saleh Mansour, Manal Mashhour Elsaid, Nouran Abd El hamid]
}

\begin{abstract}
The This study is based on the study of the impact of economic freedom on foreign direct investment in the Arab countries, namely, (Algeria, Jordan, UAE, Bahrain, Saudi Arabia, Sudan, Iraq, Kuwait, Morocco, Yemen, Tunisia, Comoros, Djibouti, Syria, Oman, Qatar, Lebanon, Libya, Egypt, Mauritania) during the period from 2008 to 2014. The measurement of foreign direct investment (FDI) by net inflows of foreign direct investment as a percentage of GDP. And measured economic freedom index of Economic Freedom published by the Wall Street Journal and the Foundation Heritage, in terms of economic freedom ten elements such as business freedom, freedom of trade, fiscal freedom, government spending, monetary freedom, investment freedom, financial freedom, property rights, freedom from corruption, and freedom of action. The regression results show that the commercial freedom negatively linked to foreign direct investment, while the economic freedom, financial freedom, financial freedom, and the freedom to work positively linked to foreign direct investment. The business freedom, trade freedom government spending, monetary freedom, investment freedom, financial freedom, property rights, freedom from corruption does not significantly affect the results. And the respect of GDP and GDP per capita is significantly positive and in foreign direct investment. This means that the net foreign direct investment flows to the Arab countries attracted by the organizational efficiency and the size of the market, instead of the rule of law, limited government and open markets.
\end{abstract}

Keywords-Keywords: foreign direct investment, economic freedom, the Arab States, the gross domestic product (GDP), investment freedom, labor freedom, fiscal freedom, government spending, monetary freedom, freedom from corruption, labor freedom, property rights, business freedom.

\section{1-Authors Name/ Rasha Saleh Mansour (Author)}

line1: Institute of Agricultural Economic Research-Agricultural Research Center

line2: Egypt

${ }^{2-}$ Authors Name/ Manal Mashhour Elsaid (Author) line1 Researcher -Desert Research Center line2: Egypt

\footnotetext{
3- Authors Name/ Nouran Abd El hamid (Author) line1: Agricultural College / Mansoura University line2: Egypt
}

\section{Introduction}

Be foreign direct investment (FDI) is always an important driver of global economic growth. The competing countries are all the more foreign direct investment flows, and this applies to both developed and developing countries, where more than foreign direct investment flows to developing countries more than those to developed countries, where it reached the foreign direct investment in the United States about 225.4 billion dollars in 2014. And Arab countries have played (Algeria, Jordan, UAE, Bahrain, Saudi Arabia, Sudan, Iraq, Kuwait, Morocco, Yemen, Tunisia, Comoros, Djibouti, Syria, Oman, Qatar, Lebanon, Libya, Egypt, Mauritania) a vital role in attract foreign direct investment and the share of foreign direct investment in the global foreign direct investment flows, has been reduced foreign direct investment to Arab countries after the global financial crisis, from about 97.28 billion dollars in 2008, to about 36.34 billion US dollars in 2014, a decline of about $62.6 \%$ of 2008.

This study is trying to study the reasons that Arab countries can attract more foreign direct investment flows by focusing on the relationship between economic freedom and foreign direct investment in the Arab countries. It is measured economic freedom index of Economic Freedom published by the Wall Street Journal and the Foundation Heritage, which includes ten elements such as (Economic Freedom, Business Freedom, Trade Freedom, Fiscal Freedom, Government Spending, Monetary Freedom, Investment Freedom, Financial Freedom, Property Rights, Freedom from Corruption, Labor Freedom). This paper contributes not only to study the general index of economic freedom, but also the study of 10 components of the index. Are selected control variables to measure the size of the market, and the growth of the market and the degree of openness, the next section presents the methodology, details of the results of the study, and the conclusion of that study.

\section{Methodology}

This paper examines foreign direct investment to the Arab countries - (Algeria, Jordan, UAE, Bahrain, 
Saudi Arabia, Sudan, Iraq, Kuwait, Morocco, Yemen, Tunisia, Comoros, Djibouti, Syria, Oman, Qatar, Lebanon, Libya, Egypt, Mauritania) - during the period from 2000 to 2014 and measured by net foreign direct investment flows of foreign direct investment as a percentage of GDP. It is measured economic freedom index of Economic Freedom published by the Wall Street Journal and the Heritage Foundation. There are 11 scale, namely: the first measure is the economic overall freedom, while following the 10 measures are: (Economic Freedom, Business Freedom, Trade Freedom, Fiscal Freedom, Government Spending, Monetary Freedom, Investment Freedom, Financial Freedom, Property Rights, Freedom from Corruption, Labor Freedom).

Are selected four variables to control based on: GDP per capita as a proxy for the size of the market, total imports of goods and services as a percentage of GDP, as a proxy for the degree of openness, the annual growth of GDP rate of growth of the market as an agent. The annual collection of data for the index and the ten components of economic freedom from the Heritage Foundation and the World Bank. This is the annual collection of data flows, net foreign direct investment and other factors, from the World Development Indicators, and be the multiple regression models are as follows:

FDIit $=\mathrm{a}+\mathrm{b}$ 1GDPGit + b2IMPORTSit $+\mathrm{b} 31 \mathrm{n}$

(GDPPC) it + b4ln (GDP) it +

b5EconomicFreedomIndexit + e (1)

It indicates where:

FDI: foreign direct investment, which is net foreign direct investment as a percentage of gross domestic product flows.

GDPG: annual GDP growth rate.

IMPORTS: Total imports of goods and services as a percentage of GDP.

GDPPC: GDP per capita.

Economic Freedom Index: Index of Economic Freedom

is the 11 measures of economic freedom indicators (Economic Freedom, Business Freedom, Trade Freedom, Fiscal Freedom, Government Spending, Monetary Freedom, Investment Freedom, Financial Freedom, Property Rights, Freedom from Corruption, Labor Freedom).

* Has been used Jarque-Bera test: is a test used to determine the validity and quality of the form, where they can use to test the statistical hypothesis that the normal distribution of data, distributed or subject to the null hypothesis, namely that the data be twisted and Splayed plus.

\section{Research results and discussion}

\section{A. descriptive statistics}

Net FDI inflows amounted to Arab countries by about $\$ 97.3$ billion in 2008 , then down to about $\$ 36.3$ billion in 2014, a decline of about $62.6 \%$ in 2008 . The total foreign direct investment alone top, at about $\$$ 16.7 billion to Saudi Arabia at a rate of about $35.8 \%$, followed by the UAE, where about 8.21 billion dollars at a rate of about $15.7 \%$, then Egypt about $\$ 4.7$ billion at a rate of about $8.9 \%$, and reached its lowest in the Comoros about 0.006 billion dollars at a rate of about $0.01 \%$ of the total countries Arabic, during the period (2000-2014) .table (1).

Table (1) descriptive statistics of the variables: average net foreign direct investment for the Arab States flows, at about $2.75 \%$ of GDP, the average annual GDP growth rate of about $10.2 \%$, the average total imports amounted to about $21.8 \%$ as a percentage of GDP. The overall economic freedom amounted to about 50.7 which is not high compared with developed countries. The highest index is financial freedom, about 73.3, followed by monetary freedom around 67.5, followed by government spending of about 57.9, followed by Trade Freedom about 57, followed by Business Freedom of about 57.9, followed by the Economic Freedom of about 50.7, followed by Investment Freedom of about 39.8, followed by Financial Freedom, about 39, followed by Labor Freedom of about 36.3, followed by about 36.1 Property Rights, while the lowest index is freedom from corruption, about 35.6.

The correlations matrix displays between variables in Table II. It was found that all the links seem low, but that the relationship between gross domestic product (GDP) and economic freedom is high, and this will be taken into account when the regression procedure.

\section{B. Regression Results}

Regression results details in Table III shows that there are 11 downhill, with different economic freedom indicators, where there is a correlation between gross domestic product (GDP) and economic freedom, are deleted GDP variable (GDP) in the first slope when the Index of Economic Freedom is the independent variable. The results indicate that the general index of economic freedom and morally positive affect on foreign direct investment at 10\% ,. However, the results of the 10 mixed components: where Freedom 
Proc. of the Third Intl. Conf. on Advances in Management, Economics and Social Science - MES 2015. Copyright (C) Institute of Research Engineers and Doctors, USA .All rights reserved.

ISBN: 978-1-63248-081-1 doi: 10.15224/ 978-1-63248-081-1-41

Trade adversely affect foreign direct investment at a level of $10 \%$, while the Economic Freedom, Fiscal Freedom, Financial Freedom a positive impact on foreign direct investment at a level of $10 \%$, while the Labor Freedom effective positively on foreign direct investment at a level of $5 \%$, while the Business Freedom, Government Spending, Monetary Freedom, Investment Freedom, Property Rights, Freedom from Corruption, do not affect the results. These results mean that the net foreign direct investment flows to the Arab countries attracted by the organizational efficiency instead of the rule of law, limited government, and open markets.

Moreover, the imports variable positively affect the foreign direct investment in all Downgrades, and this is consistent with the existence of economic freedom, especially with the spread of trade exchange between Arab countries. As it turns out research during the period 2008-2014 that the great openness which may mean that foreign direct investment to the Arab countries determinants changes over time. It turns out that GDP positively affect foreign direct investment, and GDP per capita has a negative impact on foreign direct investment, and noted that the increase of the size of the market could attract more foreign direct investment flows.

\section{Figures and Tables}

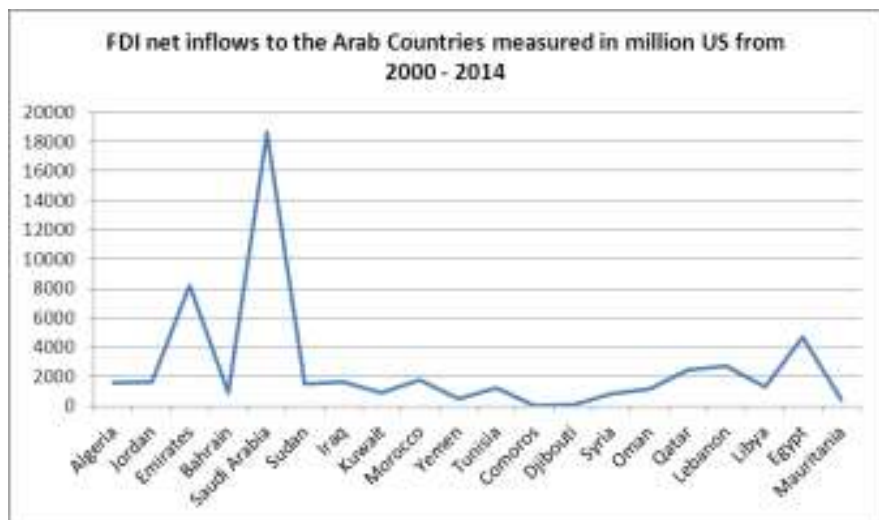

Figure 1: FDI net inflows to the Arab Countries measured in million US from 2000 - 2014

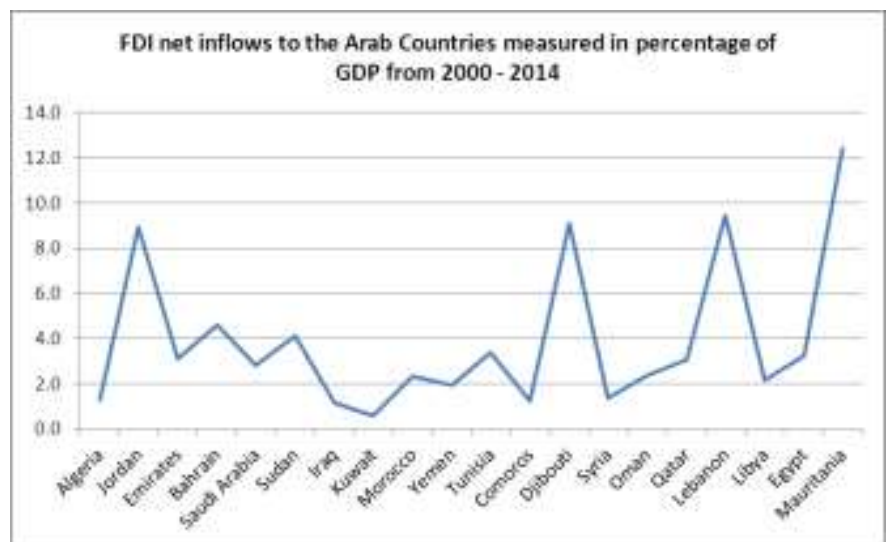

Figure 2: FDI net inflows to the Arab Countries measured in percentage of GDP from $2000-2014$

Table (I): Descriptive Statistics of Variables

\begin{tabular}{|c|c|c|c|c|c|c|}
\hline & Mean & Max & Min & $\begin{array}{l}\text { Std. } \\
\text { Dev. }\end{array}$ & $\begin{array}{l}\text { Jarque- } \\
\text { Bera }\end{array}$ & Probability \\
\hline GDP & 81172.6 & 746248.5 & 201.9 & 118814.3 & 2113.3 & 0.000 \\
\hline IMPORTS & 11421.7 & 262000.0 & 18.5 & 33409.7 & 13657.8 & 0.000 \\
\hline GDPPC & 11433.1 & 93714.1 & 18.4 & 17483.0 & 868.1 & 0.000 \\
\hline FDI & 2232.4 & 39455.9 & 0.1 & 4584.0 & 12093.1 & 0.000 \\
\hline FDIP & 7.0 & 497.6 & 0.0 & 33.0 & 362351.0 & 0.000 \\
\hline GDPGP & 10.2 & 11.2 & 9.3 & 0.5 & 18.0 & 0.000 \\
\hline IMPORTSP & 21.8 & 1229.7 & 0.9 & 74.1 & 696132.2 & 0.000 \\
\hline LNGDP & 10.2 & 13.5 & 5.3 & 1.8 & 39.4 & 0.000 \\
\hline LNGDPPC & 8.3 & 11.5 & 2.9 & 1.6 & 1.049 & 0.592 \\
\hline $\begin{array}{l}\text { Economic } \\
\text { Freedom }\end{array}$ & 50.7 & 77.7 & 0.0 & 21.9 & 121.6 & 0.000 \\
\hline $\begin{array}{l}\text { Property } \\
\text { Rights }\end{array}$ & 36.1 & 90.0 & 0.0 & 20.0 & 2.1 & 0.358 \\
\hline $\begin{array}{l}\text { Freedom } \\
\text { from }\end{array}$ & 35.6 & 90.0 & 0.0 & 21.4 & 4.9 & 0.087 \\
\hline $\begin{array}{l}\text { Corruption } \\
\text { Fiscal } \\
\text { freedom }\end{array}$ & 73.3 & 99.9 & 0.0 & 30.9 & 124.0 & 0.000 \\
\hline $\begin{array}{l}\text { Government } \\
\text { Spending }\end{array}$ & 57.9 & 90.3 & 0.0 & 24.7 & 120.5 & 0.000 \\
\hline $\begin{array}{l}\text { Business } \\
\text { Freedom }\end{array}$ & 55.1 & 87.5 & 0.0 & 23.2 & 88.7 & 0.000 \\
\hline $\begin{array}{l}\text { Labor } \\
\text { Freedom }\end{array}$ & 36.3 & 97.0 & 0.0 & 32.7 & 34.6 & 0.000 \\
\hline $\begin{array}{l}\text { Monetary } \\
\text { Freedom }\end{array}$ & 67.5 & 94.0 & 0.0 & 25.9 & 288.9 & 0.000 \\
\hline $\begin{array}{c}\text { Trade } \\
\text { Freedom }\end{array}$ & 57.0 & 90.0 & 0.0 & 26.4 & 62.3 & 0.000 \\
\hline $\begin{array}{l}\text { Investment } \\
\text { Freedom }\end{array}$ & 39.8 & 75.0 & 0.0 & 21.4 & 16.9 & 0.000 \\
\hline $\begin{array}{l}\text { Financial } \\
\text { Freedom }\end{array}$ & 39.0 & 90.0 & 0.0 & 22.5 & 7.3 & 0.026 \\
\hline
\end{tabular}

Note: FDI stands for net inflows of foreign direct investment as a percentage of GDP, GDPG stands for GDP annual growth rate, IMPORTS stands for total imports of goods and services as a percentage of GDP, LN_GDPPC stands for natural logarithm of GDP per capita, LN_GDP stands for natural logarithm of GDP. 
Proc. of the Third Intl. Conf. on Advances in Management, Economics and Social Science - MES 2015.

Copyright (C Institute of Research Engineers and Doctors, USA .All rights reserved.

ISBN: 978-1-63248-081-1 doi: 10.15224/ 978-1-63248-081-1-41

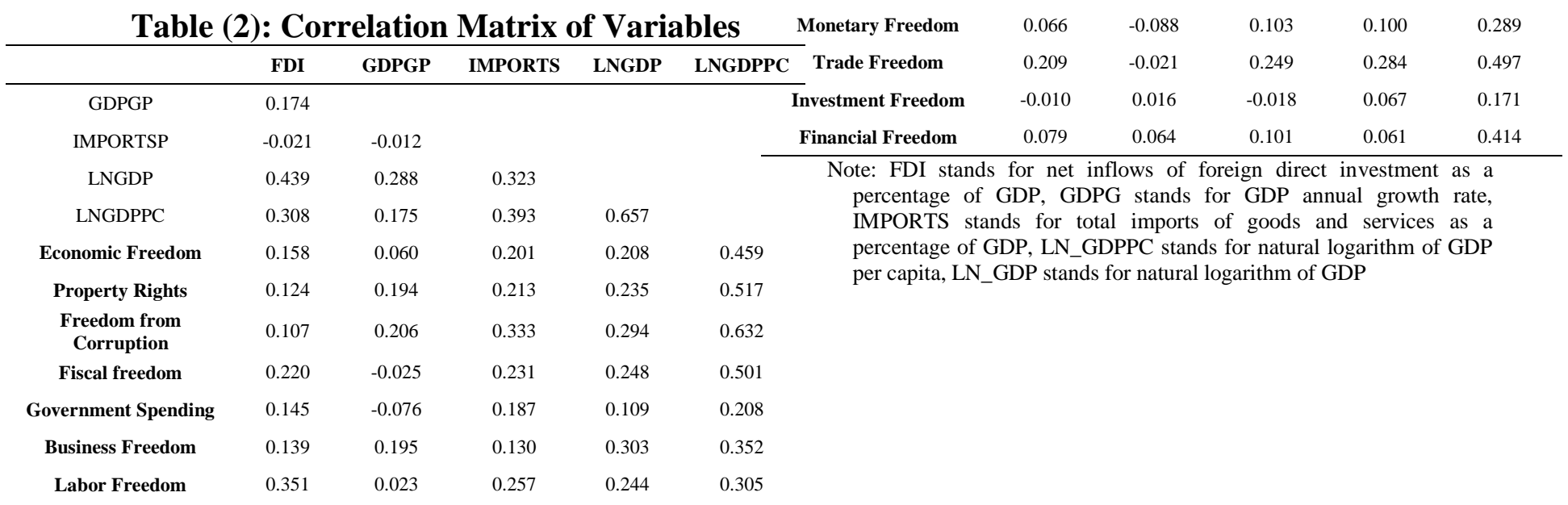

Table (3): Regression Results on Foreign direct Investment to Arabian countries

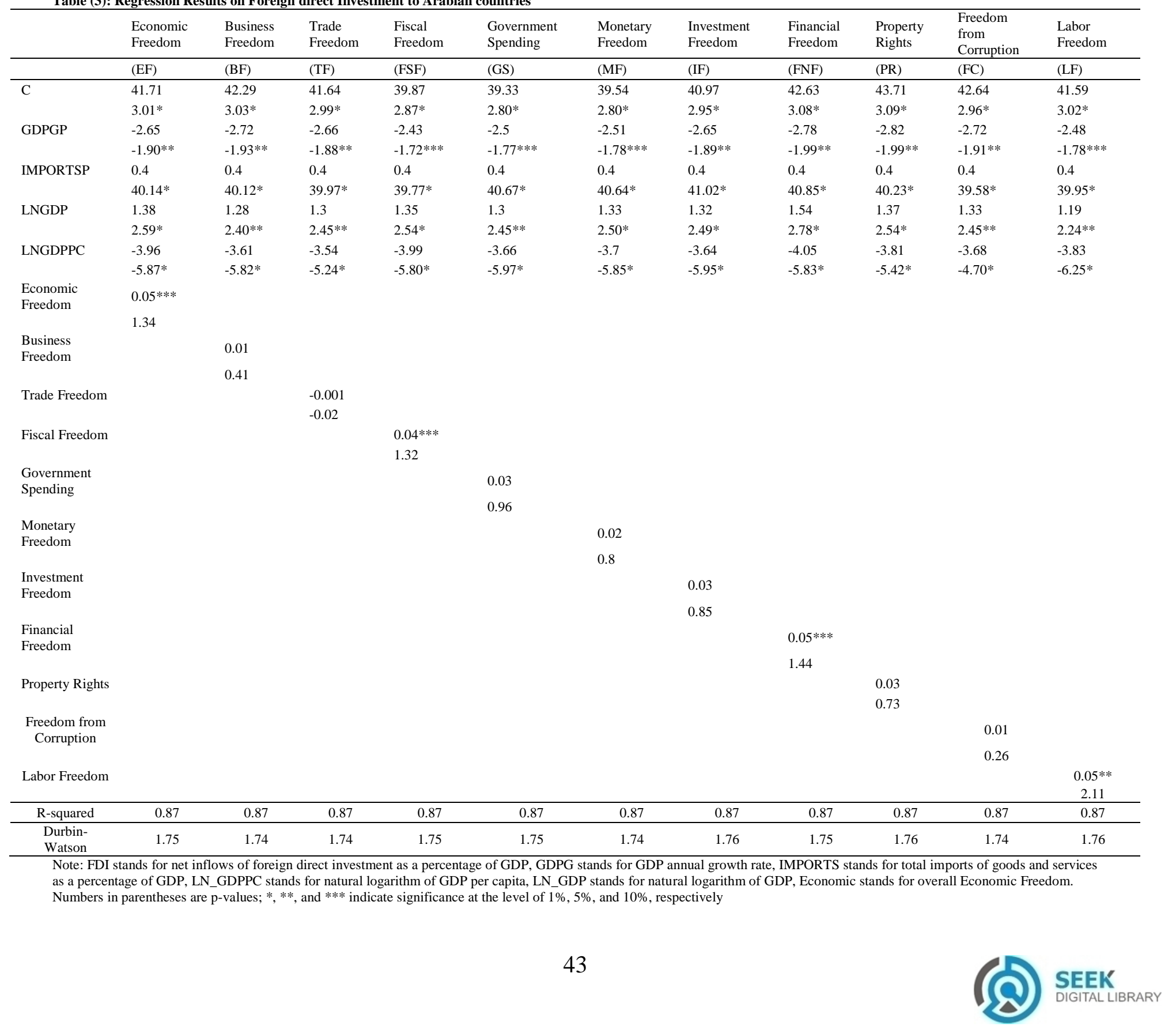


Proc. of the Third Intl. Conf. on Advances in Management, Economics and Social Science - MES 2015.

Copyright (C) Institute of Research Engineers and Doctors, USA .All rights reserved.

ISBN: 978-1-63248-081-1 doi: 10.15224/ 978-1-63248-081-1-41

\section{Conclusion}

This paper studied the relationship between economic freedom and foreign direct investment in the Arab countries during the period 2008- 2014 and is measured economic freedom index of Economic Freedom published by the Wall Street Journal and the Foundation Heritage, which includes ten elements such as (Economic Freedom, Business Freedom, Trade Freedom , Fiscal Freedom, Government Spending, Monetary Freedom, Investment Freedom, Financial Freedom, Property Rights, Freedom from Corruption, Labor Freedom),

The regression results are mixed year for the index of economic freedom and the ten elements. It was found that the general index of economic freedom was significantly and adversely affect Trade Freedom adversely affect foreign direct investment at a level of $10 \%$, while the Economic Freedom, Fiscal Freedom, Financial Freedom, Labor Freedom positive impact on foreign direct investment, The Business Freedom, Government Spending, Monetary Freedom, Investment Freedom, Property Rights, Freedom from Corruption, do not affect the results.

Moreover, the imports variable positively affect foreign direct investment, and this is consistent with the existence of economic freedom, especially with the spread of trade exchange between Arab countries. It turns out that the great openness, which may mean that foreign direct investment to the Arab countries determinants change over time. It turns out that GDP positively affect foreign direct investment, and show that GDP per capita has a negative impact on foreign direct investment, and noted that the increase of the size of the market could attract more foreign direct investment flows.

\section{References}

[1] http://www.heritage.org/

[2] http://www. albankaldawli.org/

[3] UNCTAD, "The rise of BRICS FDI and Africa," Global Investment Trends Monitor," special edition, pp. 1-10, March 2013.

[4] S. Griffith-Jones, "Financing global development: the BRICS New Development Bank," German Development Institute, Briefing paper, $13 / 2015$.

[5] D. Popa and L. Carp, "The influence of foreign trade and foreign direct investment on BRICS economic growth," Global Virtual Conference, pp. 162-167, April 2013.

[6] S. Elfakhani and W. Mackie, "An analysis of net FDI drivers in BRIC countries," Competitiveness Review, vol. 25, issue 1, pp. 98-132, 2015.

[7] D.K. Malhotra, L. Russow and R. Singh, "Determinants of foreign direct investment in Brazil, Russia, India, and China," International Journal of Business, Accounting, and Finance, vol. 8, number 1, pp. 130148, Spring 2014

[8] N. Vijayakumar, P. Sridharan and K. C. S. Rao, "Determinants of FDI in BRICS countries: a panel analysis," International Journal of Business Science and Applied Management, vol. 5, issue 3, pp. 1-13, 2010.
[9] C. F. de Angelo, R. V. Eunni and N.M.M.D. Fouto, "Determinants of FDI in emerging markets: evidence from Brazil," International Journal of Commerce and Management, vol. 20, issue 3, pp. 203-216, 2010.

[10] M. Singhania and A. Gupta, "Determinants of foreign direct investment in India," Journal of International Trade Law and Policy, vol. 10, issue 1, pp. 64-82, 2011.

[11] R. M. Quazi and S. Tandon, "Foreign direct investment and investment climate in China and India: a comparative analysis," International Journal of Business and Economics Perspectives, vol. 6, number 2, pp. 70-79, Fall 2011.

[12] D. E. Thomas and R. Grosse, "Country-of-Origin Determinants of Foreign Direct Investment in An Emerging Market: The Case of Mexico," Journal of International Management, vol. 7, pp. 59-79, 2001.

[13] Q. Sun, W. Tong and Q. Yu, "Determinants of Foreign Direct Investment across China," Journal of International Money and Finance, vol. 21, pp. 79-113, 2002.

[14] S. H. Lim, "How Investment Promotion Affects Attracting Foreign Direct Investment: Analytical Argument and Empirical Analysis," International Business Review, vol. 17, pp. 39-53, 2008.

[15] J.W. Fedderke and A.T. Romm, "Growth Impact and Determinants of Foreign Direct Investment into South Africa, 1956-2003," Economic Modelling, vol. 23, pp. 738-760, 2006.

[16] R. B. Sambharya and A. A. Rasheed, "Does economic freedom in host countries head to increased foreign direct investment?" Competitiveness Review, vol. 25, issue 1, pp. 2-24, 2015.

[17] R. Quazi, "Economic freedom and foreign direct investment in east Asia," Journal of the Asia Pacific Economy, vol. 12, no. 3, pp. 329- 344, August 2007.

[18] A. Mathur and K. Singh, "Foreign direct investment, corruption and democracy," Applied Economics, vol. 45, pp. 991-1002, 2013.

[19] C. Tintin, "Foreign direct investment inflows and economic freedoms: evidence from central and eastern European countries," Advances in Business-related Scientific Research Journal, vol. 4, number 1, pp. 1- 12, 2013.

[20] Dr.Li Li ,Economic Freedom and Foreign Direct Investment in BRICS Countries , The Third Intl. Conf. on Advances in Social Science, Management and Human Behaviour - SMHB 2015, Copyright (C) Institute of Research Engineers and Doctors, USA .All rights reserved, ISBN: 978-1-63248-067-5 